\title{
Diclofop-methyl: A phenoxy propionate herbicide with multiple toxic effects in mouse embyro fibroblast (NIH/3T3) cell line
}

\author{
Müzeyyen ÇELİKSÖZ, Bahar ULUS, Ezgi ÖZTAŞ, Gül ÖZHAN
}

\begin{abstract}
Diclofop-methyl is a selective post-emergence graminicide from the phenoxy propionate group of herbicides to be developed for control of wild oats, millets, and other annual grass weeds. Diclofop-methyl usage is limited in various grass weed species due to its toxic effect and exposure risks. However, total annual usage of is approximately 750.000 pounds in United States, and more in Asia. Therefore, we aimed to investigate diclofopmethyl's toxic potentials in vitro and the following assays were used; MTT assay for cytotoxicity, comet assay for genotoxicity, generation of reactive oxygen species (ROS), malondialdehyde (MDA) and glutathione (GSH) for the potential of oxidative damage in mouse embryo fibroblast (NIH/3T3) cell line. Diclofop-methyl was observed to reduce the cell viability in a concentration manner and the half maximal inhibitory
\end{abstract}

concentration $\left(\mathrm{IC}_{50}\right)$ value was $301.7 \mu \mathrm{M}$. Diclofop-methyl caused DNA damage and oxidative stress at the concentrations between 12.5-400 $\mu \mathrm{M}$. Tail intensities were at the range of 1.24$58.21 \%$ with increasing concentrations, which are approximately $\leq 1.63$-fold of the negative control. Also, MDA levels were increased $\geq{ }^{3} 11.4$-fold of the negative control that denotes lipid peroxidation was induced. However, there was no significant increment in the ROS and GSH levels at all concentrations. In view of the fact that ROS has not been detected, despite its level of MDA proffers, the idea that oxidative damage may have been caused by other mechanisms. Our results indicate that diclofopmethyl was cytotoxic, genotoxic and might have oxidative damage potential in vitro conditions.

Keywords: Diclofop-methyl; reactive oxygen species; malondialdehyde; Comet assay
Müzeyyen Çeliksöz, Bahar Ulus, Ezgi Öztaş, Gül Özhan Department of Pharmaceutical Toxicology, Faculty of Pharmacy, Istanbul University, 34116 Istanbul, Turkey

\author{
Corresponding Author: \\ Gül Özhan \\ e-mail: gulozhan@istanbul.edu.tr
}

Submitted / Gönderilme: 29.03.2017 Revised / Düzeltme: 13.07.2017 Accepted / Kabul: 15.07.2017

How to cite this article : Çeliksöz M, Ulus B, Öztaş E, Özhan G. Diclofopmethyl: A phenoxy propionate herbicide with multiple toxic effects in mouse embyro fibroblast (NIH/3T3) cell line. Marmara Pharm J 2017; 21 (4): 992-997

\section{Introduction}

Pesticides are continuously required for global food production to control all kinds of pests and weeds; however, they remain as residues in food, water and air $[1,2]$. Herbicides are widely used, and have an intensive biological effects on pests [3]. Diclofob-methyl, a member of aryloxyphenoxy propanoate herbicide group, inhibits acetyl-CoA carboxylase (ACCase) which is a key enzyme in long-chain fatty acid biosynthesis [4]. Diclofob-methyl is used to control a wide range of grasses due to its high target selectivity and low nontarget toxicity $[1,5,6]$. Total annual usage of diclofop-methyl in United States is approximately 750.000 pounds of active ingredient, 1.5 -fold more in China $[1,7]$.

Diclofop-methyl is a possible endocrine disrupter and a carcinogen [8]. By the United States Environmental Protection Agency [6], diclofop-methyl is classified as a likely human carcinogen, and placed category II for the oral exposure route, category III for the dermal exposure route; and category IV for the inhalation exposure route. Diclofop-methyl inhibits 
the biosynthesis of sex pheromone in moths and precludes mating success, thereby reduces insect population [9]. Besides, it is significantly associated with hypospadias [10]; the main end points include skeletal effects, decreased fetal weight, and distended ureters in rodent [6]. Diclofopmethyl is also classified as a developmental toxicant [6]. The acceptable daily intake (ADI) and the maximum acceptable concentration (MAC) in drinking water are $0.001 \mathrm{mg} / \mathrm{kg} / \mathrm{day}$ and $0.009 \mathrm{mg} / \mathrm{L}$, respectively [11].

We aimed to investigate underlying pathways of toxic effects observed in diclofop-methyl exposure. For this purpose, it was performed MTT and comet assays for cyto- and genotoxicity, respectively, and the determination of ROS, MDA and GSH levels for oxidative damage in mouse embryo fibroblast (NIH/3T3) cell line.

\section{Materials and methods}

Chemicals: Diclofop-methyl standard (Cat. No. 51338-273. Pestenal) was obtained from Riedel-de Haen (Seelze, Germany). The stock solution was prepared by dissolving in dimethyl sulphoxide (DMSO) at the $100 \mathrm{mM}$ final concentration and kept at $-20^{\circ} \mathrm{C}$. The working concentrations were in the range of 1-500 $\mu \mathrm{M}$. Cell culture supplements were obtained from Multicell Wisent (Quebec, Canada) and all plastic materials were purchased from Corning (Amsterdam, The Netherlands). 3-[4,5-dimethylthiazol2-yl]-2,5-diphenyl-tetrazolium bromide (MTT) was obtained from Sigma-Aldrich Chemicals Co. (St. Louis, MO, USA). 2',7'-Dichloro-dihydro-fluorescein diacetate $\left(\mathrm{H}_{2}\right.$-DCFDA) dye was obtained from Invitrogen (Waltham, MA USA). MDA-ELISA kit was purchased from Elabscience Biotechnology Co. (Bethesda, MD, USA). All other chemicals were purchased from Sigma-Aldrich Chemicals Co. (St. Louis, MO, USA) and Merck (Darmstadt, Germany) as required grades for biochemical assays.

Cell culture: The mouse embryo fibroblast cell line (NIH/3T3, CRL-1658) was purchased from the American Type Culture Collection (ATCC, Manassas, USA), and cultured in Dulbecco's Modified Eagle's Medium : Nutrient Mixture F-12 (DMEM F12) supplemented with 10\% fetal bovine serum (FBS), 100 units $/ \mathrm{mL}$ of penicillin, and $100 \mu \mathrm{g} / \mathrm{mL}$ of streptomycin at $37^{\circ} \mathrm{C}$ in a humidified $5 \% \mathrm{CO}_{2}$ incubator. Subculture was done by trypsinisation in every 2-3 days as the attached cells become confluent.

MTT assay: The cytotoxic potential was assessed by MTT assay as previously described by Abudayyak et al. based on color changes by activity of the enzyme are used as a cytotoxicity endpoint [12]. Briefly, $10^{4}$ cells were seeded into each well of 96-well plate and after overnight incubation; cells were treated with various concentrations of diclofopmethyl for $24 \mathrm{~h}$. Cell culture medium, 1\% sodium dodecyl sulphate (SDS), $1 \%$ DMSO and were used as growth, positive and solvent controls, respectively. $20 \mu \mathrm{L}$ MTT dye $(5 \mathrm{mg} / \mathrm{mL})$ was then added and plates were incubated for further $3 \mathrm{~h}$. The supernatant was discarded, $100 \mu \mathrm{L}$ DMSO was added, and the optical densities (ODs) were read at $590 \mathrm{~nm}(670$ $\mathrm{nm}$, reference) using a microplate spectrophotometer system (Epoch, Bad Friedrichshall, Germany). The inhibition of enzyme activity was calculated and compared to that of negative control cells. Then, the half maximal inhibitory concentration $\left(\mathrm{IC}_{50}\right)$ values were expressed as the sample concentration that caused an inhibition of $50 \%$ in enzyme activities in cells.

Comet assay: The genotoxic potential was assessed by comet assay as previously described by Alpertunga et al. [13]. Briefly, $10^{5}$ cells were seeded into each well of 24well plate and after overnight incubation; cells were treated with various concentrations of diclofop-methyl for $24 \mathrm{~h}$. Hydrogen peroxide $\left(\mathrm{H}_{2} \mathrm{O}_{2}\right)(100 \mu \mathrm{M})$ and $1 \%$ DMSO were used as positive and solvent controls, respectively. Cells were detached by trypsinisation and re-suspended in phosphate buffered saline (PBS). Then, cells were mixed with prewarmed low melting agarose (LMA) and layered onto microscope slides pre-coated with normal-melting point agarose (NMA). After overnight lysis at $4^{\circ} \mathrm{C}$, DNA was unwinded for $20 \mathrm{~min}$ in cold-fresh electrophoresis buffer followed by electrophoresis $4^{\circ} \mathrm{C}$ for $20 \mathrm{~min}(20 \mathrm{~V} / 300 \mathrm{~mA})$. Then, slides were neutralized and stained with $20 \mu \mathrm{g} / \mathrm{mL}$ ethidium bromide. The number of DNA breaks was scored under a fluorescent microscope (Olympus BX53, Tokyo, Japan) at 400X using an automated image analysis system (Comet Assay IV, Perceptive Instruments, Suffolk, UK). DNA damage to individual cells was expressed as a percentage of DNA in the comet tail intensity $[14,15]$.

Oxidative stress parameters: Oxidative stress was evaluated with the levels of ROS, MDA and GSH. The abundance of ROS was quantified utilizing $\mathrm{H}_{2}$-DCFDA fluorescence dye at $517-527 \mathrm{~nm}$ by flow cytometry (Acea Novocyte 1000, California, USA). ROS production in NIH/3T3 cells was measured using the redox sensitive fluorescent dye $\mathrm{H}_{2}$-DCFDA. Briefly, $3 \times 10^{5}$ cells were seeded into each well of 6-well plate. After overnight incubation, the cells were treated with different concentrations of diclofop-methyl for $24 \mathrm{~h}$. The cells were detached by trypsinisation, washed 
in PBS twice and re-suspended in $1 \mathrm{~mL}$ PBS. Then, $20 \mu \mathrm{M}$ $\mathrm{H}_{2 .}$ DCFDA was added into each tube and incubated at $37^{\circ} \mathrm{C}$ for $30 \mathrm{~min}$; and analyzed by flow cytometry.

MDA and GSH levels were measured by ELISA kits according to the manufacturer's instructions. The assay is based on biotin double antibody sandwich technology and during the reactions MDA or GSH in the sample is compete with a fixed amount of MDA or GSH on the solid phase supporter for sites on the biotinylated antibody. Briefly, $10^{5}$ cells were seeded into each well of 96 -well plate. After overnight incubation, the cells were treated with different concentrations of diclofop-methyl and cell culture medium as negative control for $24 \mathrm{~h}$. Then, $50 \mu \mathrm{L}$ of the supernatant was added into microplate which was pre-coated with a fixed amount of MDA or GSH. Immediately then, specific antibody was added into each well and plate was incubated at $37^{\circ} \mathrm{C}$ for $45 \mathrm{~min}$. Excess conjugate and unbound sample was washed from the plate, and $100 \mu \mathrm{L}$ Avidin conjugated to Horseradish Peroxidase (HRP) was added and incubated at $37^{\circ} \mathrm{C}$ for $30 \mathrm{~min}$. Then, plate was washed for five times and $90 \mu \mathrm{L}$ substrate reagent was added and plate was incubated at $37^{\circ} \mathrm{C}$ for further $15 \mathrm{~min}$. The enzyme-substrate reaction was terminated by the addition of a sulphuric acid solution and the OD was immediately read at $450 \mathrm{~nm}$ using microplate spectrophotometer system. Results were expressed $\mathrm{ng} / \mathrm{mL}$ for MDA levels and mmol per mg of protein for GSH levels by using a standard calibration curves.

Statistical analysis: All experiments were done in triplicate and each assay was repeated twice. Data was expressed as mean \pm standard deviation (SD). The significance of differences between unexposed and exposed cells was calculated by one-way ANOVA Dunnett t-test using SPSS version 20.0 for Windows (SPSS Inc., Chicago, IL). A two sided $p$ values of less than 0.05 were selected as the levels of significance.

\section{Results and discussion}

There are many reports about the adverse effects of pesticides on human and environmental health [16]. Aryloxy phenoxy propionic acid herbicides are one of the major pesticide groups. Diclofop-methyl is a selective, post emergence aryloxy phenoxy propionic acid herbicide primarily used to control wild oat (Avena fatua L.) and other annual graminaceous weeds in wheat, barley, and soybeans [3, 17]. Exposure to some of these pesticides may lead to modifications in the genetic material thereby causing mutagenicity, carcinogenicity, teratogenicity and immunotoxicity [16]. As it is well known, genotoxic potential of pesticides is a risk factor for longterm effects with carcinogenic and reproductive toxicity [3, 18]. Department of National Health and Welfare conducted a two-year mouse feeding/oncogenicity study [19]. In the study, diclofop-methyl was administered at doses up to of $20 \mathrm{mg} / \mathrm{g}$ in the diet (about $1 \mathrm{mg} / \mathrm{kg}$ bw/day). A no observed effect level (NOEL) of $0.1 \mathrm{mg} / \mathrm{kg} /$ day was observed, based on systemic effects, which is approximately $2 \mathrm{mg} / \mathrm{g}$ of diclofopmethyl in the diet. In the present study, diclofop-methyl reduced the cell viability in a concentration manner. The cell viability at 31.25-1000 $\mu \mathrm{M}$ concentrations of diclofop-methyl was showed in Figure 1, and the $\mathrm{IC}_{50}$ value was calculated as $301.7 \mathrm{mM}$.

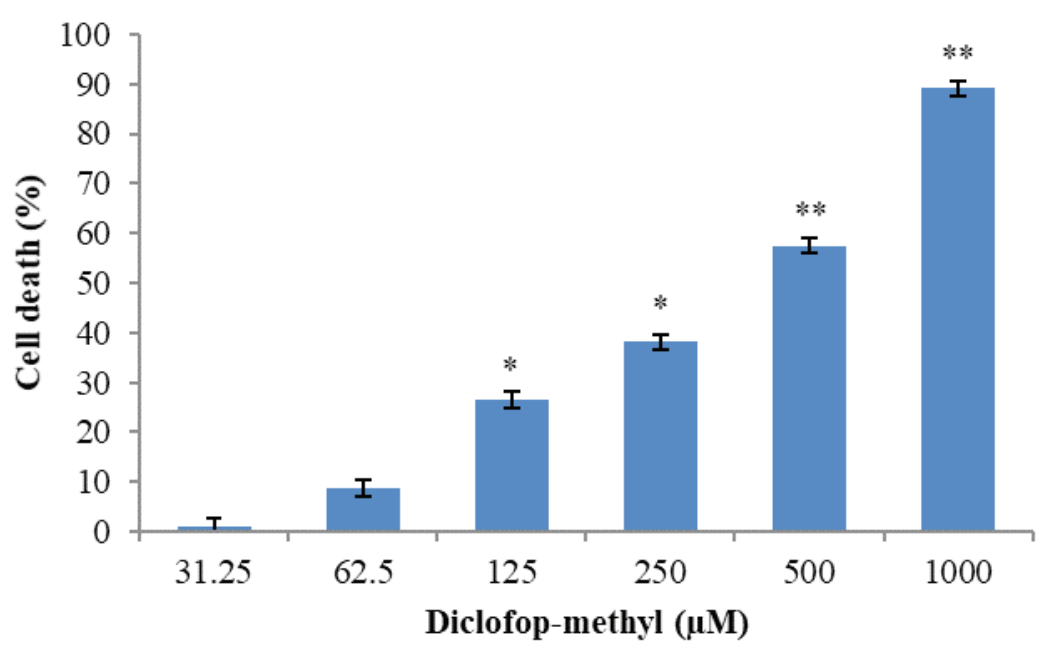

Figure 1. Effects of diclofop-methyl on cell viability by MTT.

${ }^{*}$ Significantly different from DMSO control group $(\mathrm{p}<0.05) .{ }^{* *}$ Significantly different from DMSO control group $(\mathrm{p}<0.01)$ 
In the present study, the genotoxic potential of diclofopmethyl evaluated by comet assay was showed in Figure 2 . Based on our cytotoxicity results, the range of $12.5-400 \mu \mathrm{M}$ diclofop-methyl was selected as the exposure concentrations. Diclofop-methyl significantly induced DNA damage in a concentration manner. Tail intensities were observed 9.05, 36.7 and $58.76 \%$ ( $\leq 1.63$ fold) at the 100,200 and $400 \mu \mathrm{M}$ exposure concentrations, respectively. At 12.5 and $25 \mu \mathrm{M}$, the maximum increase was 1.24 -fold ( $p>0.05$; data not shown in Figure 1) in comparison to negative control. In positive control $\left(100 \mu \mathrm{M} \mathrm{H}_{2} \mathrm{O}_{2}\right)$, the tail intensity was ranged from 55.25-56.96\%. Similar to our data, Unal et al. [3] found diclofop-methyl was a cyto- and genotoxic agent in human lymphocytes and mouse bone-marrow cells. They observed that a high degree of DNA damage was in lymphocytes from $6.00 \pm 0.75$ to $12.79 \pm 1.22$, respectively. Also, they indicated diclofop-methyl to be induced chromatid and chromosome breaks, fragments, sister chromatid unions, chromatid exchanges, dysenteric chromosomes, polyploidy, and endoreduplication.

Reactive oxygen species (ROS) generation was measured as an increase in the fluorescence of dichlorofluorescein diacetate-loaded cells [20]. As to ROS potential of diclofopmethyl, there was no significant increase in the DCFDA fluorescence at all concentrations (Figure 3).
Abd-Alrahman et al. [1] indicated that diclofop-methyl induced significant elevations in MDA levels and reduction in total thiol proteins. Similarly, we observed diclofop-methyl significantly increased MDA level in all concentrations $(p \leq 0.05)$ (Figure 4$)$. The MDA level was determined as $3.98 \mathrm{ng} / \mathrm{mL}$ in $1 \% \mathrm{DMSO}$, and 53.82, 80.45, $45.39 \mathrm{ng} / \mathrm{mL}$ in increasing concentrations, respectively. The MDA level was ${ }^{3} \geq 11.4$ folds when compared to negative control even if it was decreased at the maximum exposure concentration (500 $\mathrm{mM}$ ) as to the other studied exposure concentrations. For the decrease, the reason could be the higher cell death level (57.4\%) at $500 \mathrm{mM}$ of diclofop-methyl.

In the present study, GSH levels were also determined in the range of 0-500 mM concentrations of diclofop-methyl. However, no changes were observed after diclofop-methyl exposure on GSH levels. The GSH levels were 1.22, 1.19, 1.21 and $1.451 .13 \mathrm{mmol} / \mathrm{mg}$ protein, respectively, at $62.5,125,250$ and $500 \mathrm{mM}$ exposure concentrations. GSH depletion was $\leq 2.45 \%$ when compared to negative control $(1.13 \mathrm{mmol} / \mathrm{mg}$ protein) (data not shown). The results should be confirmed by in vivo studies including different exposure time points and dosages of diclofop-methyl treatment.

In conclusion, our results clearly demonstrate that diclofopmethyl is cytotoxic, genotoxic and has the potential of

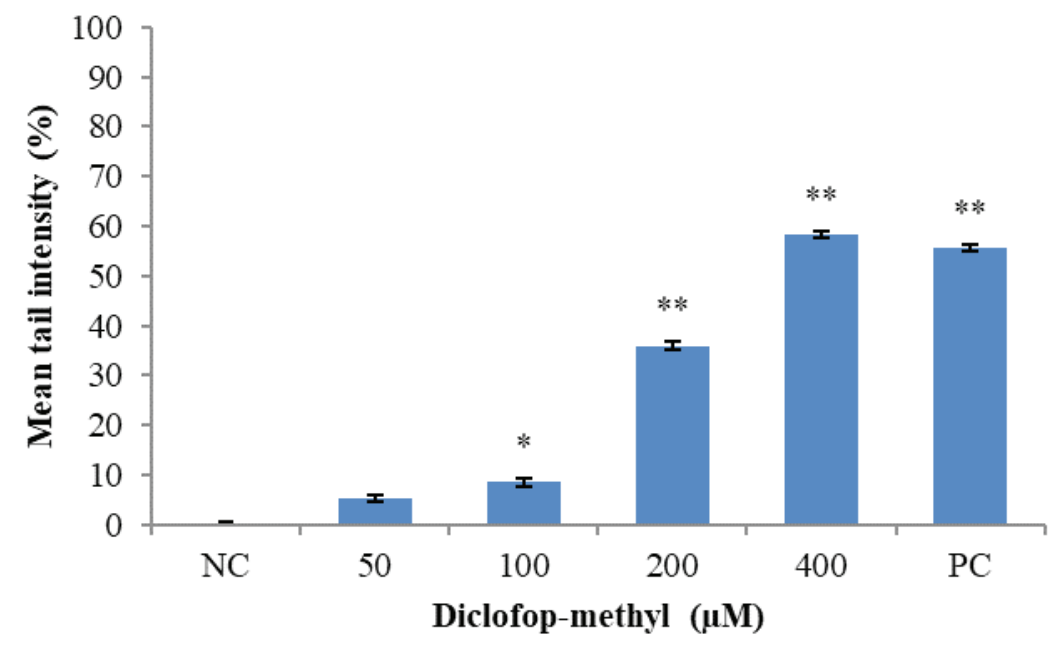

\begin{tabular}{lcccccc}
\hline & \multicolumn{7}{c}{ Concentration $(\mu \mathrm{M})$} \\
& $\mathrm{NC}$ & $\mathbf{5 0}$ & $\mathbf{1 0 0}$ & $\mathbf{2 0 0}$ & $\mathbf{4 0 0}$ & $\mathrm{PC}$ \\
\cline { 2 - 7 } Tail intensity $(\%$, mean \pm SD) & 0 & $5.40 \pm 0.11$ & $8.50 \pm 0.23$ & $36.02 \pm 1.24$ & $58.21 \pm 2.25$ & $55.54 \pm 3.14$ \\
\hline
\end{tabular}

Figure 2. Evaluation of genotoxic potentials of diclofop-methyl by comet assay. $\mathrm{NC}(1 \% \mathrm{DMSO})$ and $\mathrm{PC}\left(100 \mu \mathrm{M} \mathrm{H}_{2} \mathrm{O}_{2}\right)$ mean negative and positive controls, respectively.

${ }^{*}$ Significantly different from DMSO control group $(p<0.05){ }^{* \star}$ Significantly different from DMSO control group $(p<0.01)$. 


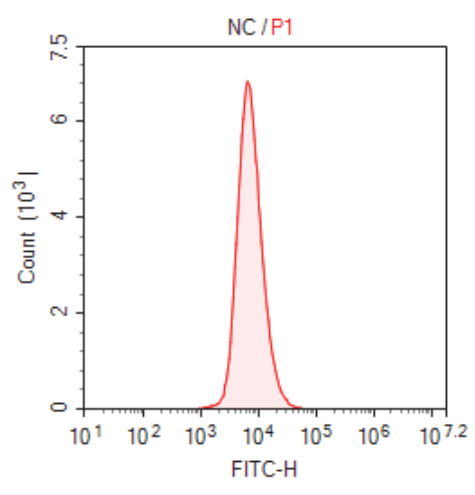

(a)

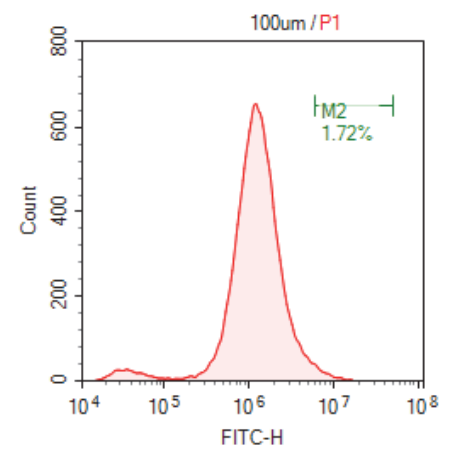

(d)

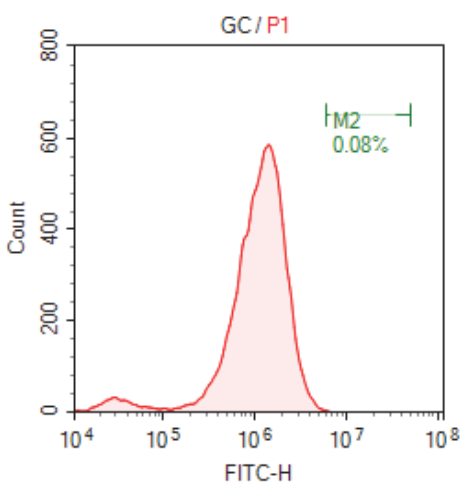

(b)

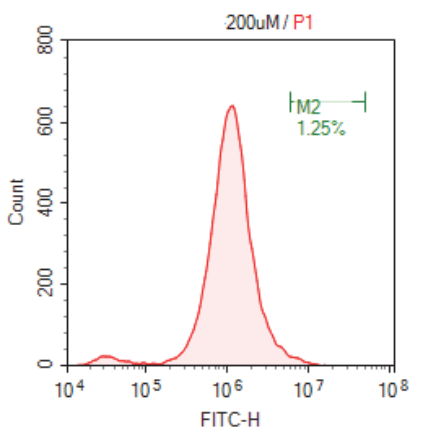

(e)

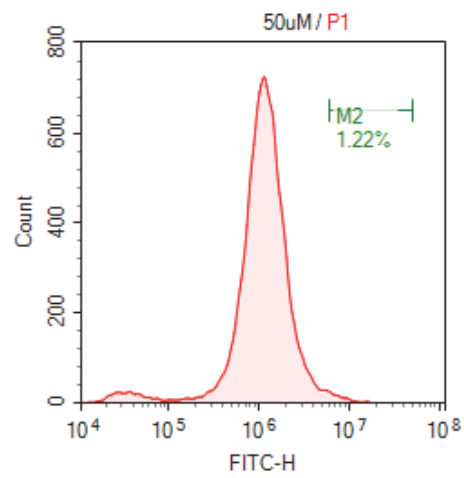

(c)

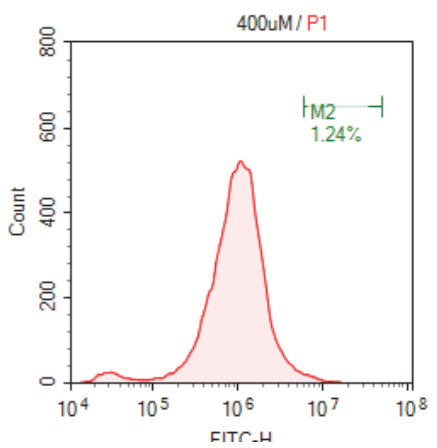

(f)

Figure 3. Effect of diclofop-methyl on intracellular ROS formation in NIH/3T3 cells detected by flow cytometry with FITC. (a) Negative control (NC; the cell not incubated with $\mathrm{H}_{2}$-DCFDA), (b) growth control (GC) (c)-(f) treatment with 0, 50, 100, 200 and $400 \mu \mathrm{M}$ diclofop-methyl, respectively. Original representative histogram of intensity DCFDA fluorescence (FITC) in gated population of cells (P1) for each histogram was shown. M2 indicates the DCFDA fluorescence defining the percentage of dichlorofluorescein diacetate-loaded cells.

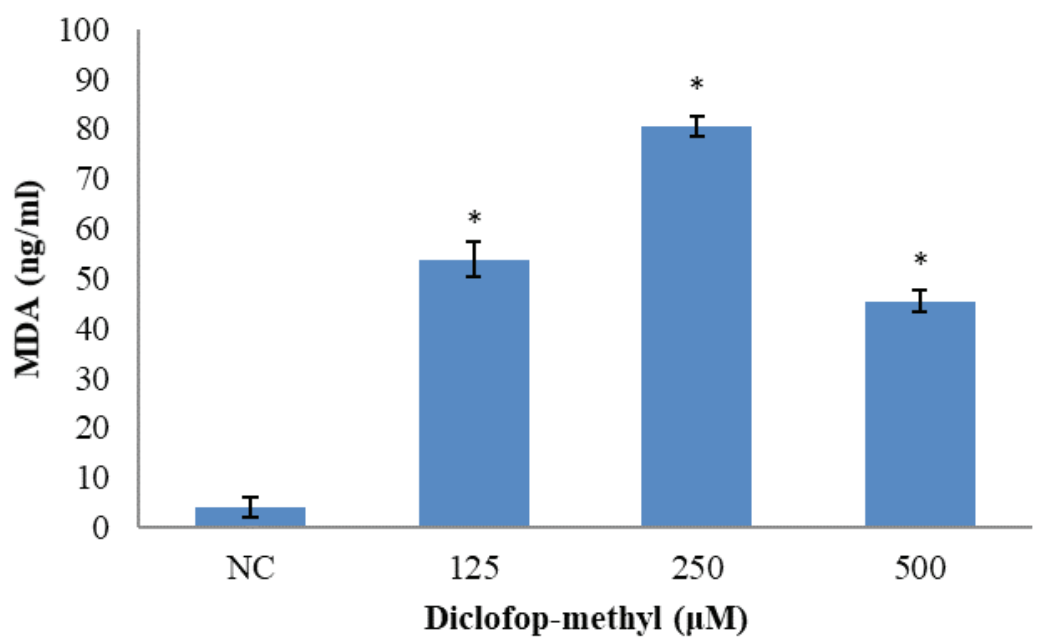

Figure 4. MDA levels with the diclofop-methyl exposure. NC (1\% DMSO) means negative control. ${ }^{*}$ Significantly different from negative group $(p<0.05)$. 
causing oxidative damage in mouse embryo fibroblast (NIH/3T3) cells in vitro. Elevated MDA levels are powerful evidence for oxidative stress; however, ROS and GSH levels were unchanged. Although ROS has not been detected, the high MDA levels, as the marker of oxidative damage in membrane, might indicate that the oxidative damage could be occurred by other mechanisms. There is a need for safety measure to prevent people from being exposed to agricultural toxic substances. With the limited literature knowledge about diclofop-methyl, further studies, especially in vivo conditions, are required to clarify its mechanism of action.

Acknowledgement: The work was supported by the Research Fund of Istanbul University (Project No: BYP-2017-23676).

\section{REFERENCES}

1. Abd-alrahman SH, Elhalwagy MEA, Kotb GA, Farid H, Farag AAG, Draz HM, Isa AM, Sabico S . Exposure to difenoconazole, diclofop-methyl alone and combination alters oxidative stress and biochemical parameters in albino rats. Int J Clin Exp Med 2014; 7: 3637-46.

2. Larsen K, Najle R, Lifschitz A, Mate ML, Lanusse C, Virkel GL. Effects of sublethal exposure to a glyphosate-based herbicide formulation on metabolic activities of different xenobioticmetabolizing enzymes in rats. Int J Toxicol 2014; 33: 307-18.

3. Unal F, Yüzbaşıoğlu D, Yılmaz S, Akıncı N, Aksoy H. Genotoxic effects of chlorophenoxy herbicide diclofop-methyl in mice in vivo and in human lymphocytes in vitro. Drug Chem Toxicol 2011; 34: 390-5.

4. Shimabukuro R, Hoffer B. Enantiomers of diclofop-methyl and their role in herbicide mechanism of action. Pestic Biochem Physiol 1995; 51: 66-82.

5. Hongming $\mathrm{L}, \mathrm{Xu} \mathrm{L}$, Zhaojian G, Fan Y. Isolation of an aryloxyphenoxy propanoate (AOPP) herbicide-degrading strain Rhodococcus ruber JPL-2 and the cloning of a novel carboxylesterase gene (feh). Brazilian J 2015; 432: 425-32.

6. United States Environmental Protection Agency (U.S. EPA). Prevention, pesticides and toxic substances. EPA738-F-00-007 (7508C) R.E.D. FACTS diclofop-methyl. Washington, DC; 2000.
7. Ding H, Lu H, Lavoie M, Xie J, Li Y, Lv X. Unraveling the toxicity mechanisms of the herbicide diclofop-methyl in rice: modulation of the activity of key enzymes involved in citrate metabolism and induction of cell membrane anion channels. J Agric 2014; 62: 10654-60.

8. Ye J, Wang L, Zhang Z, Liu W. Enantioselective physiological effects of the herbicide diclofop on cyanobacterium Microcystis aeruginosa. Environ Sci 2013; 47: 3893-901.

9. Eliyahu D, Applebaum S, Rafaeli A. Moth sex-pheromone biosynthesis is inhibited by the herbicide diclofop. Pestic Biochem Physiol 2003; 77: 75-81.

10. Meyer KJ, Reif JS, Rao Veeramachaneni DN, Luben TJ, Mosley BS, Nuckols JR. Agricultural pesticide use and hypospadias in Eastern Arkansas. Environ Health Perspect 2006; 114: 158995.

11. Methods Analytical and Health Effects. Diclofop-Methyl 1987; (March 1987): 1-2.

12. Abudayyak M, Öztaş E, Arici M, Özhan G. Investigation of the toxicity of bismuth oxide oxide nanoparticles in various cell lines. Chemosphere 2017; 169: 117-23.

13. Alpertunga B, Kara M, Abudayyak M. Effects of prochloraz on DNA damage, lipid peroxidation and antioxidant system in vitro. Toxicol Mech Methods 2014; 24: 268-75.

14. Speit G, Hartmann A. The comet assay (Single-Cell Gel Test) a sensitive genotoxicity test for the detection of DNA damage and repair. DNA Repair Protoc Eukaryot Syst 1999; 203-12.

15. Collins AR. The comet assay for DNA damage and repair: principles, applications, and limitations. Mol Biotechnol 2004; 26: 249-61.

16. Sandal S, Yilmaz B. Genotoxic effects of chlorpyrifos, cypermethrin, endosulfan and 2,4-D on human peripheral lymphocytes cultured from smokers and nonsmokers. Environ Toxicol 2011; 26: 433-42.

17. DiTomaso J, Brown P, Stowe A, Linscott D. Effects of diclofop and diclofop-methyl on methyl on membrane potentials in roots of intact oat, maize, and pea seedlings. Plant 1991; 95: 1063-9.

18. Bolognesi C, Morasso G. Genotoxicity of pesticides: potential risk for consumers. Trends Food Sci Technol 2000; 11: 182-7.

19. Department of National Health and Welfare. Unpublished studies; summary of evaluations by the Food Directorate (1988)

20. Cañas N, Valero T, Villarroya M, Montell E. Chondroitin sulfate protects $\mathrm{SH}-\mathrm{SY} 5 \mathrm{Y}$ cells from oxidative stress by inducing heme oxygenase-1 via phosphatidylinositol 3-kinase/ Akt. J Pharmacol Exp Ther 2007; 323: 946-53. 